\title{
Síndrome de Guillain-Barré ¿seguimos en el siglo XX?
}

\section{Guillain-Barré syndrome, still in XX century?}

\author{
Raquel Fernández González, José Luis Jiménez Martínez \\ Complejo Hospitalario Universitario Ourense, España
}

\section{RESUMEN}

La primera descripción del síndrome de Guillain-Barré fue en 1916, surgiendo en ese mismo siglo avances en el manejo de esta entidad, de la mano de la plasmaféresis y las inmunoglobulinas intravenosas.

Pasadas varias décadas desde entonces, el objetivo del presente artículo es repasar esta patología así como los avances más recientes en su manejo.

Palabras Clave: Síndrome Guillain-Barré; Poliradioculoneuropatía; plasmaféresis; Inmunoglobulinas

Desde la primera publicación en 1916 en la que Georges Charles Guillain, Jean-Alexandre Barré y André Strohl describen dos casos del síndrome que más tarde llevará sus nombres, surgieron en el último tercio del mismo siglo avances en su tratamiento: la plasmaféresis y las inmunoglobulinas intravenosas.

Pasadas varias décadas desde entonces, el objetivo del presente artículo es repasar esta patología así como los avances más recientes.

El síndrome de Guillain-Barré (SGB) es una polineuropatía aguda inmunomediada con una incidencia de 1-2 casos/100000 habitantes/año; es más frecuente en varones y su incidencia aumenta con la edad. Se conocen diferentes subtipos, con distinta distribución geográfica, siendo en Europa la variante predominante la poliradiculoneuropatía desmielinizante inflamatoria aguda (PDIA) y en Asia la neuropatía axonal motora aguda (AMAN).

Su patogenia no es bien conocida, pero la hipótesis es que, tras una infección, se produce un mimetismo molecular con componentes del sistema nervioso periférico originando una respuesta inmune. Esta hipótesis planteada por primera vez en 1990 a raíz de dos casos de AMAN con antecedente de infección por Campylobacter jejuniy anticuerpos antigangliósidos positivos, se apoya en el hecho de que dos tercios de los pacientes con SGB tienen un antecedente de infección respiratoria o gastrointestinal, normalmente en las 2-3 semanas previas al inicio de la clínica (aunque puede ser hasta en las 6 semanas previas).

Los patógenos relacionados son muchos, pero destacan el Campylobacter jejuni, Citomegalovirusy Virus influenza; también se ha relacionado con la infección por Haemophylus influenzae, E. coli, Mycoplasma pneumoniae, VEB, VHS, VIH, VHEy Virus Zika. En los últimos años, además se han detectado casos relacionados con inmunobiológicos

\section{ABSTRACT}

Since the first report of Guillain-Barré syndrome in 1916, appeared -in this century- new treatments, plasma exchange and intravenous immunoglobulin.

Several decades ago, this report try to review this syndrome and the advances in treatment.

Keywords: Guillain-Barré syndrome; Polyradiculoneuropathy; plasmapheresis; Immunoglobulins.

La clínica consiste en pérdida de fuerza, rápida, progresiva y ascendente, de inicio en extremidades inferiores -si bien en un $10 \%$ de los casos tiene inicio en miembros superiores 0 facial- asociada a areflexia o hiporeflexia (en más del 90\%). La pérdida de fuerza se gradúa con la escala Hughes. El cuadro se acompaña de parestesias en manos y pies hasta en el $67 \%$ de los casos, en más de un $50 \%$ se asocia afectación de nervios craneales y más de la mitad tienen dolor ${ }^{2}$.

Además de la clínica compatible, en los criterios diagnósticos de Brighton se incluyen dos pruebas complementarias: la punción lumbar y el electromiograma (EMG). Lo característico del SGB es la disociación albúmino-citológica en el líquido cefalorraquídeo (LCR), pero hasta en un $50 \%$ de los casos el LCR es normal en la primera semana, por lo que unas proteínas normales no descartan el diagnóstico; lo que sí debería hacernos plantear otro diagnóstico alternativo es la presencia de más de 50 células $u g / \mathrm{mL}^{2}$. El EMG es útil no sólo para establecer el diagnóstico sino también para definir el subtipo, siendo la desmielinización predominante en la variante PDIA y el Síndrome de Miller-Fisher (SMF) y el daño axonal en AMAN y AMSAN.

La complicación más relevante a la hora de manejar a estos pacientes es el fracaso respiratorio, ya que hasta un $20 \%$ requieren ventilación mecánica (VM). Detectar los pacientes en riesgo de presentarla ha sido objetivo de varios estudios. Recientemente se ha establecido la escala EGRIS para estratificar ese riesgo en la que se tiene en cuenta el tiempo desde el inicio de los síntomas a la hospitalización, la afectación facial/ bulbar y la fuerza medida con la escala MRC ${ }^{3}$. En el estudio realizado por Walgarrd et al. para establecer los factores de riesgo de necesidad de ventilación prolongada, la media de días en VM fue de 28 días, y se estableció un mayor riesgo en aquellos pacientes con afectación del deltoides (imposibilidad para elevar de la cama los brazos) y/o con daño axonal 0 
denervación en el EMG ${ }^{4}$, por lo que los autores recomiendan valorar traqueostomia precoz en estos pacientes.

El tratamiento para esta entidad fue inicialmente exclusivamente medidas de soporte. En el año 1984 se realizaron los primeros estudios en los que comparaba esta medida con la plasmaféresis (PF), con resultado favorable en el grupo tratado con ésta última. En 1992 se realizó otro ensayo comparando plasmaféresis con inmunoglobulinas intravenosas (lgs), concluyendo que eran tan efectivas como la PF. Posteriormente se han realizado varios estudios que comparan ambas terapias, estableciéndose en la última revisión de la Cochrane que son equivalentes ${ }^{5,6}$.

Se han analizado otros tratamientos, como los corticoides, que según la Cochrane no aportan beneficio, incluso hay mayor mortalidad en el grupo tratado, por lo que no se recomiendan? Hay pequeños estudios, con bajo nivel de evidencia en los que se analizó el tratamiento con IFN, BDNF y filtrado de LCR. Recientemente, atendiendo a la fisiopatología, se están ensayando tratamientos con anticuerpos monoclonales. Por el momento, el único estudio publicado es con eculizumab, en este estudio randomizado doble-ciego se incluyeron $34 \mathrm{pa}$ cientes (23 casos y 11 controles), y -si bien no se alcanzó el objetivo primario (un $50 \%$ de pacientes independientes para deambular al mes)- parece que hay mejores resultados en el grupo tratado, aunque son precisos más estudios al respecto para recomendar su uso.

EI SGB tiene una evolución monofásica, alcanzando su nadir normalmente en las primeras 2 semanas, tras lo que se produce un periodo meseta con posterior recuperación progresiva. Uno de los retos a los que nos enfrentamos son aquellos casos en los que no se produce mejoría tras el primer tratamiento; sucediendo hasta en un $40 \%$ de los casos a las 4 semanas. En esta situación, en la práctica clínica, la inercia es plantear un segundo tratamiento, y a la vista de que las únicas terapias que han demostrado beneficio hasta el momento son las lgs y la plasmaféresis, las opciones serían: un cambio de tratamiento, repetir el administrado previamente o una combinación de ambos. Son pocos los trabajos en los que se analiza el beneficio de un segundo tratamiento, y en la actualidad no existe evidencia de que lo aporte ${ }^{1}$. El pasado año se publicó un estudio en el que se evaluó la efectividad de tratamiento de rescate (con lgs o plasmaféresis) tras un tratamiento inicial con Igs; $y$-si bien no se alcanzó la significación estadística- los autores concluyen que en pacientes seleccionados podría ser beneficioso $0^{9}$. Este año se ha publicado otro estudio en el que se valora si la administración de un segundo ciclo de inmunoglobulinas en pacientes con mal pronóstico, definido con una puntuación mEGOS 6-12, aporta beneficio en términos de fuerza medida con la escala Hughes. En él se incluyeron 237 pacientes (199 controles y 38 casos), sin obtenerse beneficio en el grupo tratado ${ }^{10}$.

La conclusión tras la revisión realizada es que estamos ante una entidad en la que hay mucho camino por recorrer en su manejo, ya que los tratamientos empleados actualmente son prácticamente los mismos del siglo pasado. Parece que el futuro vendrá de la mano de la inmunoterapia, pero son pocos los avances en esta línea por el momento.

\section{BIBLIOGRAFÍA}

1. Sonja E. Leonhard, Melissa R. Mandarakas, Francisco A. A. Gondim et al. Diagnosis and management of Guillain-Barré syndrome in ten steps. Nature Reviews Neurology, 2019, 15: 671-683.

2. Christiaan Fokke, Bianca van den Berg, Judith Drenthen et al. Diagnosis of GuillainBarre syndrome and validation of Brighton criteria. Brain 2014: 137; 33-34.

3. Walgaard C., Lingsma HF., Ruts L. et al. Prediction of respiratory insufficiency in Guillain-Barré syndrome. Ann Neurol. 2010 Jun;67(6):781-7.

4. Christa Walgaard1, Hester F. Lingsma, Pieter A. van Doorn1 et al. Tracheostomy or Not: Prediction of Prolonged Mechanical Ventilation in Guillain-Barre Syndrome. Neurocrit Care (2017) 26:6-13.

5. Raphael JC, Chevret S, Hughes RA, et al. Plasma exchange for Guillain-Barre syndrome. Cochrane Database Syst Rev 2012;(7):CD001798.

6. Hughes RA, Swan AV, van Doorn PA. Intravenous immunoglobulin for Guillain-Barré syndrome. Cochrane Database Syst Rev 2014(9):CD002063.

7. Hughes R.A, Brassington R., Gunn A et al. Corticosteroids for Guillain-Barré syndrome. Cochrane Database Syst Rev 2016: CD001446

8. Sonoko Misawa, Satoshi Kuwabara, Yasunomi Sato et al. Safety and efficacy of eculizumab in Guillain-Barré syndrome: a multicentre, double-blind, randomised phase 2 trial. Lancet Neurol 2018; 17:519-29

9. Ayman Mahmoud Alboudi, Pournamy Sarathchandran, Samar Sameer Geblawi et al. Rescue treatment in patients with poorly responsive Guillain-Barre syndrome. SAGE Open Medicine 2019; 7:1-5

10. Christa Walgaard, Bart C. Jacobs, Hester F. Lingsma et al. Original research: Second IVIg course in Guillain-Barré syndrome patients with poor prognosis: the non-randomized ISID study. J Neurol Neurosurg Psychiatry 2020; 91:113-121 


\title{
Recordando la parotiditis en la era del SARS-CoV-2
}

\author{
Remembering Parotitis in SARS-CoV-2 era
}

\author{
${ }^{1}$ Anabela Salgueiro Marques, ${ }^{2}$ Joana Diogo, ${ }^{2}$ Carolina Coelho \\ 'Internal Medicine Graduated Specialist, CUF Descobertas Hospital, Portugal. ${ }^{2}$ Internal Medicine Resident, Capuchos Hospital, Portugal.
}

\begin{abstract}
New 2019-Coronavirus (SARS-CoV-2) pandemic is presenting daily diagnostic challenges to emergency departments (ED) doctors, especially as an increasing number of atypical clinical presentations have been reported, including acute sialadenitis (most of parotid).

We present a case of a 46-year-old obese caucasian woman, with no relevant medical history, that presented in ED with complaints suggesting parotitis, with normal laboratory tests, at first with no virus isolation, confirmed by computed tomography. One week later, anosmia and dysgeusia were notice, and SARS-CoV-2 was tested and confirmed.

Authors want to alert that SARS-CoV-2 should be excluded as parotitis etiology, highly important, especially in this pandemic phase, as a way of transmission control.
\end{abstract}

Keywords: Parotitis; SARS-CoV-2.

Palabras clave: Parotiditis; SARS-CoV-2

\section{INTRODUCTION}

The New 2019-Coronavirus (SARS-CoV-2) and its worldwide pandemic is presenting daily diagnostic challenges to emergency departments (ED) doctors, especially in regard to atypical clinical presentations.

An increasing number of atypical clinical presentations have been reported, mostly gastrointestinal, dermatological and neurologic manifestations ${ }^{1}$. More recently, atypical orofacial manifestations where also been reported, including oral ulcerative and vesiculobullous lesions and acute sialadenitis (most of parotid) ${ }^{2-4}$.

\section{CLINICAL CASE}

A 46-year-old obese Caucasian woman, with no relevant medical history, presented in the ED with sudden right mandibular pain and local facial and neck swelling. She had no other systemic complaints (fever, cough, anosmia, dysgeusia, fatigue, myalgias or headache).

On examination the patient had stable vital signs, body temperature of $36,5^{\circ} \mathrm{C}$, with discrete right-sided preauricular, submandibular and face swelling. She presented a palpable induration at mandibular angle with no erythema or purulent drainage from Stenson's duct.

Laboratory tests were normal, with negative respiratory viruses, most usually responsible for parotitis (negative monospot test for Epstein-Barr virus and negative PCR for enteroviruses, influenza, parainfluenza and coxsackie viruses).

Computed tomography (Image 1) showed swelling of the right parotid gland, suggestive of acute parotitis. These inflammatory alterations extended through the inferior planes of the parotid locus with reactionary inflammatory ganglia. No lithiasis was detected by this method.

At first, we thought it was a case of parotitis secondary to duct obstruction and treated it with anti-inflammatory and beta-lactam antibiotic to prevent bacterial co-infection.

The patient got better until one week later, when the pain intensified again and anosmia and dysgeusia were notice. Polymerase chain reaction (PCR) for SARS-CoV-2 on nasopharyngeal swab was then performed and it was positive.

The patient recovered of all symptoms in five days.

\section{DISCUSSION}

Acute parotitis is an inflammatory and infectious process of the parotid gland. It can be associated with immune suppression states (such as diabetes and alcoholism), autoimmune diseases (such as Sjogren's syndrome or sarcoidosis), deficient oral hygiene, hyposalivation after medication (antidepressants), post-surgical dehydration and obstructions due to sialolithiasis, tumors or foreign body 5 .

The viral inflammation of parotid gland causing its enlargement, might block the main gland duct (Stenson's duct), leading to saliva retention and parotid tissue inflammation. The clinical diagnosis may be confirmed by gland ultrasound, contrast-enhanced computed tomography or even magnetic resonance ${ }^{5}$.

Regarding infectious etiologies, we must remember the most common viruses which cause parotitis: paramyxovirus for epidemic parotitis and enteroviruses, influenza, parainfluenza, coxsackie, Epstein-Barr-virus, herpes and even human immunodeficiency viruses for isolated cases ${ }^{4,5}$.

Capaccio et al. reported the first case of parotitis in the context of SARS-CoV-2 infection. Acute parotitis can be the first clinical sign of the new coronavirus, followed by other symptoms such as fever, myalgia, hyposmia and ageusia. In most cases, these manifestations resolve within a few days after diagnosis ${ }^{2-4}$.

SARS-CoV-2 uses angiotensin-converting enzyme 2 (ACE2) 
Figure 1

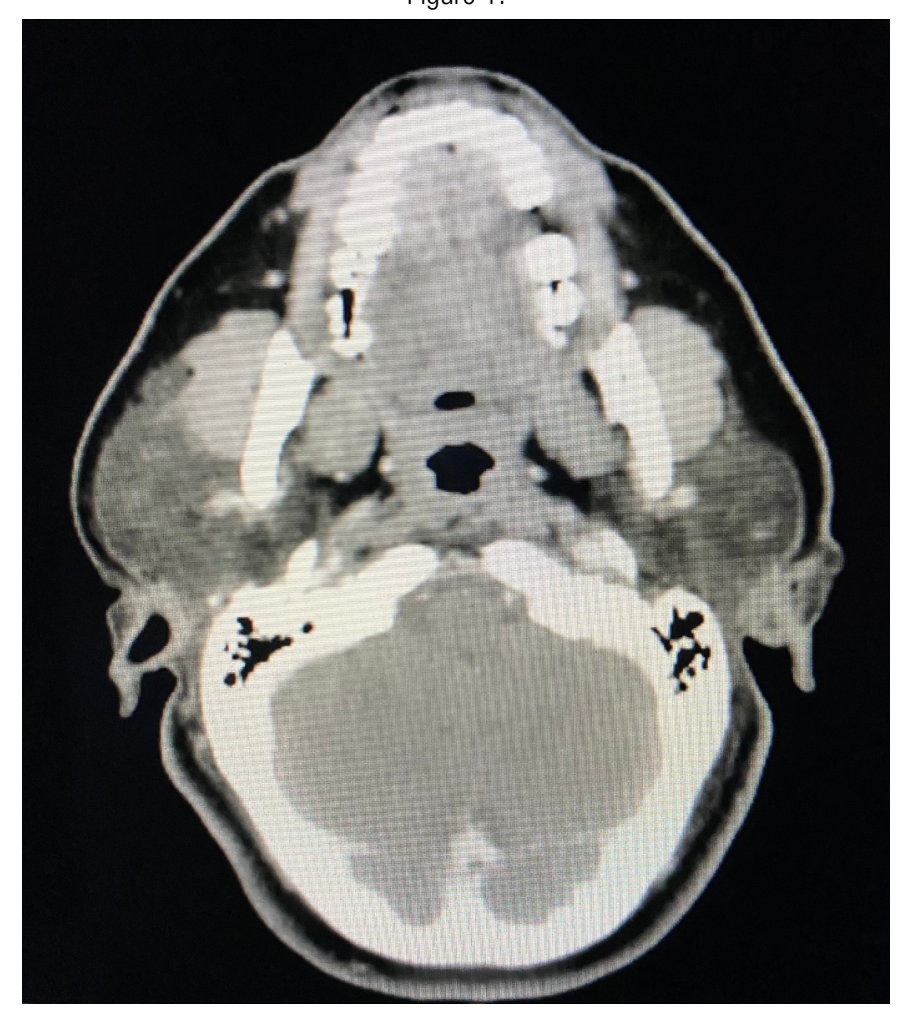

receptors to infect cells, and this receptors are highly expressed in salivary glands, what is believed to be the cause of potential targeting of SARS-CoV-2 to parotid ${ }^{2,3}$. Corroborating this, other studies reported xerostomia in a large proportion of patients with COVID-192.

The majority of parotitis resolves spontaneously evolving without recurrence or complication. The indicated treatment is symptomatic using analgesics and anti-inflammatory, such as acetaminophen or ibuprofen, local heat application, gentle glandular massage and oral hydration ${ }^{5}$. Parotitis has a relatively favorable prognosis for all forms and normally it is the underlying disease which determines the prognosis. Early otolaryngology consult should be advised ${ }^{5}$.

In conclusion, the authors want to alert all clinicians that SARS-CoV-2 should be always excluded as etiology of multiple orofacial conditions, particularly parotitis. This is of high importance, especially in this pandemic phase, with a view of a transmission control, but also in the future, we must not forget this virus as a cause of parotitis, frequently seen in our ED.

\section{CONFLICTS OF INTEREST AND SOURCE OF FUNDING}

The authors declare that there is no conflict of interest in this work.

Financiación: The authors declare that there were no external sources of study for the performance of this article.

Aspectos éticos: The authors declare that no data that allows identification of the patient appears in this article.

\section{REFERENCIAS}

1. Guan WJ, Ni ZY, Hu Y, Liang WH, Ou CQ, He JX, et al. Clinical characteristics of coronavirus disease 2019 in china. N Engl J Med. 2020 Apr;382(18):1708-20.

2. Halboub, Esam et al. Orofacial manifestations of COVID-19: a brief review of the published literature. Braz. oral res. 2020, vol.34. Epub Oct 30, 2020.

3. Lechien JR, Chetrit A, Chekkoury-Idrissi Y, Distinguin L, Circiu M, et al. Parotitis-Like Symptoms Associated with COVID-19, France, March-April 2020. Emerg Infect Dis. 2020;26(9):2270-2271.

4. J Fisher, DL Monette, KR Patel et al. COVID-19 associated parotitis. Am J Emerg Med. 2021 Jan;39:254.e1-254.e3. Epub 2020 Jun 27. 5 - Wilson M, Pandey S, Parotitis. Jan 2020, last update Dec 2020. StatPearls Publishing. Available in: https://www.ncbi.nlm.nih.gov/books/NBK560735/. 